\title{
Education activities for environment and sustainability: A Snapshot of eight New South Wales councils
}

\section{Commonwealth Journal of Local Governance \\ Issue 6: July 2010 \\ http:/lepress.lib.uts.edu.au/ojs/index.php/cjlg}

\author{
Jade Herriman $^{1}$ \\ Senior Research Consultant \\ Institute for Sustainable Futures, \\ University of Technology Sydney

\section{Emma Partridge} \\ Research Principal \\ Institute for Sustainable Futures, \\ University of Technology Sydney
}
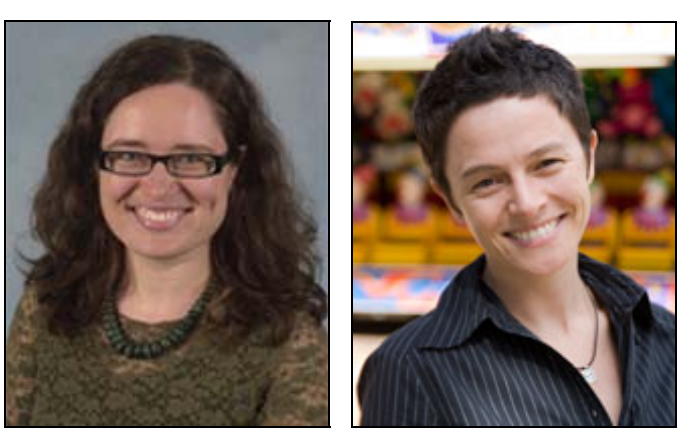

\section{Introduction}

This paper describes in brief the findings of a research project undertaken by the Institute for Sustainable Futures (ISF) at the University of Technology, Sydney, Australia. The research was commissioned by and undertaken on behalf of the New South Wales (NSW) Department of Environment, Climate Change and Water (DECCW). The aim of the project was to investigate current practices of environmental and sustainability education and engagement within local government in NSW. The research was commissioned by DECCW as the preliminary phase of a larger project that the department is planning to undertake, commencing in 2010.

An explanation of the Institute's approach to the project is provided, and the research

\footnotetext{
${ }^{1}$ The authors would like to acknowledge the following people for their willingness to be interviewed, and their valuable contributions to this project: Belinda Atkins, Mosman Municipal Council; Fiona Campbell, Randwick City Council,;Peter Davies, Ku-ring-gai Council; Chris Derksema and Melinda Cook, Council of the City of Sydney; Helene Forsythe, Bankstown City Council; Jon Francis and Kylie Tomlinson, Orange City Council; Nicole Larkin, Coffs Harbour Council; and Maree Whelan, Wyong Shire Council. We also thank Stefanie Pillora at ISF for comments on an earlier draft. Finally, thanks to Ben Roche at the Department of Environment, Climate Change and Water for commissioning the research, and providing valuable input and guidance throughout.
} 
questions that were developed to guide it are outlined. The practice note then outlines in detail the findings about the main types of programs and practices being carried out by councils, and the audiences that these programs are targeting. It focuses on describing in detail the types of programs and activities; by theme, by the sector targeted, and in terms of whether the activities are place based or event focused. The paper concludes by reflecting briefly on some of the implications - both positive and less so - of the incredibly wide range of activities and approaches that are evident in the councils studied. A more detailed analysis of the research will be written up in a future article.

\section{Methodology}

Eight local councils were chosen by DECCW as potential partners in the proposed larger project. Officers at these councils were first contacted by telephone and then sent an email link to an electronic 'background information form'. Participants completed this form, providing initial information about their council's relevant activities. This background information helped the researchers develop a basic understanding of the situation at each council, and informed the development of the interview framework. Semi-structured interviews of between 25 and 75 minutes were then conducted with the eight participants. Interviews sought to draw out more detail about the issues covered in the background information form, as well as exploring some of the more complex or subjective research questions. During the data analysis phase, the interview material, and the data provided on the background information forms, was subjected to a series of standard qualitative data analysis techniques, including a series of structured coding exercises.

Reviewing a number of key documents and considering the results of a previous Local Government and Shires Associations (LGSA) survey on a similar topic provided useful background for the research and informed the development of the research tools.

A number of limitations of the research are noted. Firstly, the findings are intended to provide only a 'snapshot' of current practice in this area, seen through the lens of the experience of the selected councils - this snapshot is not intended to be representative of the 152 councils in NSW. Secondly, researchers relied primarily on information provided by only a small number of people at each council - usually one or two - so the information provided may be incomplete. Finally, the research used a self-reporting methodology and did not seek to evaluate activities mentioned. 


\section{Terminology}

Both within the literature and among practitioners there is a range of terminology used to describe the practices and activities that this research project is interested in. Some use the term 'environmental education' (EE), others refer to 'education for sustainability' (EfS), while the United Nations uses 'Education for Sustainable Development' (EfSD) (UNESCO 2009). Still others prefer terms focussed on 'engagement' or 'behaviour change' rather than 'education'. In its work in this area, the DECCW also uses the term 'Community Education and Engagement for Sustainability' (CEE). For the purposes of this paper, these terms are used interchangeably to refer to the widest possible range of activities that councils undertake in providing members of their community with information, resources, tools or opportunities that enable and encourage them to live in more environmentally sustainable ways. Mostly the paper uses the term ‘environmental/sustainability education’ as a convenient shorthand.

\section{Approach and Research Questions}

In investigating environmental/sustainability education within the eight councils, the aim was to describe both the nature and range of different approaches and activities, and the status of such activities within the councils. Accordingly the research looked not only at the activities themselves, but also at related decision-making processes, resourcing issues, attitudes towards these activities, and their level of integration and prioritisation within council plans, organisational structures and cultures.

The research questions that were developed at the outset to guide the project were as follows:

- What kinds of education and/or community engagement for environment/sustainability are taking place in the selected councils?

- How are environmental/sustainability education programs determined?

- What staff and other resources are allocated to support community education and engagement strategies on environmental or sustainability issues?

- Is EfS/EE part of the councils' formal program commitments?

- How do the different parts of the councils perceive EfS/EE activities?

- To what extent is EE/EfS integrated across the councils' business? What are the drivers for integration/participation and buy-in across each council?

- What are the drivers and barriers to undertaking education and community 
engagement for sustainability?

- Is there an organisational culture in these councils that supports EE/EfS?

- Do the councils' education activities take an integrated approach?

\section{Findings}

\section{Range of activities being undertaken}

Councils are undertaking an enormous range of activities that can be characterised as fitting under the broad definition of environmental/sustainability education and engagement. Interviewees mentioned a large number of projects - many of which are noted below. Some of these focus on single issues and others on multiple issues. Taken together, the activities, projects and programs mentioned by these eight councils cover an extremely wide range of environmental/sustainability topics. It seems that over time there has been an increase in the number and variety of issues that councils are concerned with or are active on.

\section{Snapshot of topics: Examples of sustainability 'issues', desired behaviours or themes of interest that councils are targeting through education and engagement programs}

o Water efficiency / conservation/ demand management - in homes, schools and businesses

o Waste - how to best use recycling services, organic waste, composting, waste and consumption, sustainable living, litter

o Toxics/ pollution prevention - green cleaning (in homes and preschools), stormwater pollution prevention

o Energy efficiency - in the home, in schools, in business

o Climate change - general awareness as well as how to respond

o Coastal ecosystems, estuarine ecosystems, learning, monitoring, protection

o Terrestrial ecosystems - bushland restoration and protection (eg through the Bushcare program), monitoring and appreciating local biodiversity (focus on key threatened species)

o Transport - active transport and facilities, health links

o Gardening - native gardens, community gardens, permaculture, sustainable gardening, kitchen gardens, sustainability dimensions of food production

Within each of these 'topic areas', the kinds of activities being undertaken are very varied. The following comments of an interviewee provides a flavour of the diversity of 
activities offered in relation to the single issue of coast care:

[The activities] are basically wrapped around coast care. So they might be snorkelling or talks, slideshows about animals or they might be walks along the coast with some university lecturers that have particular knowledge in coastal systems. ... There's a guy who does a lot of presentations about safe surfing and talks about the way oceans work and sand movements and all that sort of thing.

'Education' is not always planned and 'branded' as such. Environmental/sustainability education not only happens within councils' major planned education strategies, but is also an ongoing part of many officers' roles - for example, when they respond to various queries and requests from the community, as this interviewee suggests:
We have some fairly substantial core projects that are directly linked to particular issues that are happening in our area. But there's probably quite a lot of ad hoc, at call things, like attendance at festivals and providing one-off workshops or hosting events that other organisations have developed, like the Green Plumbers and things like that.... responding to queries from local teachers or children, in relation to assignment work and things like that. So just that kind of other stuff that actually happens and we want to help and support them.

Educators were conscious of the different kinds of 'education' and learning, and had obviously given considerable thought to where on the spectrum of educational approaches their various programs and activities might sit. As a generalisation most councils appear to take a flexible and pragmatic approach, believing that a variety of approaches is most likely to be appropriate, and pointing to activities that range from information provision, to experiential learning, to explicit behaviour change strategies, all of which have some kind of 'educational' intent and effect.

The list below provides a flavour of the range of projects mentioned by the various councils:

\footnotetext{
Marine/Coastal

o CoastCare summer activities program (eg. talks, walks, presentations

o whale education project
}

\section{Climate/energy}

o climate change education, awareness and engagement

o school energy audits and activities focused on water use and biodiversity

o participation in the Nature Conservation Council Climate Consensus Project, including community workshops

o energy conservation covered in sustainability workshops 
o participation in Rotary 'sustainability expo', with water and energy saving focus

o home energy saving workshops - both as part of the Australian Conservation Foundation's (ACF) Green Home project, and independently

\section{Water}

o community engagement on water demand management

o education as part of water demand management strategies, eg. encouraging people to install water efficient hardware

o water education support for high school students and teachers

o delivery of water education as part of classroom program in schools

o development of materials and programs for primary schools including a website called Blue Planet Primary Schools; and managing a water education program for primaries schools called Central Coast Watertight

o school education and water audits

o dam / water efficiency tours

o wastewater tours

o participation in Rotary 'sustainability expo', with water and energy saving focus

o water quality monitoring with schools

o 'localising' of Sydney Water rebate programs

o home water saving workshops -as part of ACF Green Home project

o Collaboration with the local Catchment Management Authority (CMA) on water education and resource efficiency programs

\section{Biodiversity and Bushland}

o participation in the Bushcare program and support of Bushcare members e.g. by producing seasonal newsletters

o biodiversity and botany focused education programs for schools. eg the Coffs Harbour botanic garden offers curriculum linked education experiences for high school and primary school excursion groups

o bushland education through use of local wildflower garden (primarily for school children)

o education based on specific high profile species, such as talks to schools and community members on flying foxes and koalas, raising awareness of vertebrate pest species (eg foxes and Indian mynas), community education and survey work on Little Terns

o wetlands workshops

o Parks Alive program, community tree planting

o programs linked to local land use/natural resource issues such as the education component of Wyong's Estuary Management Plan

o Native Haven, schools planting program

\section{Food}

o involvement in establishing a Local Food Futures Alliance, which will have an action plan that will include community education 
Waste

o waste and recycling focused education initiatives linked to Councils waste contract (most if not all councils mentioned this)

o educational use of a resource management centre for residential and in some cases for industry (eg. Orange City Council is planning this kind of work with NetWaste)

o recycling centre where old bikes are fixed and donated to charity for less privileged residents to use for transport

o waste workshops (composting, worm farming) as part of ACF Green Home project

o organic waste trial in cafes

o Wastewatchers program in schools, 'rubbish free lunch' challenge

\section{Transport}

o bike safety awareness, promotion of bike racks, literature on safe bike riding

o Bike Week activities

o 'Transport Challenge' encouraging year 11 school students to use public transport to get around the city

\section{Programs for different sectors}

As well as covering a wide range of topics, and encompassing a diversity of activities, councils are also targeting a variety of different audiences, from children to adults, residents to businesses, individuals and groups. Councils mentioned a wide range of tailored programs for different sectors. For example, in the case of the City of Sydney, specialised programs range from an energy program for commercial offices, to a waste program for small business, a collaboration with Housing NSW (the state government department) on issues for low income earners and public housing tenants, a residential environmental actions strategy with a focus on residents of high density dwellings, to more 'general public' events like the annual Live Green event, and a series of 'City Talks'. Some of the sector-specific activities mentioned are summarised below.

\section{- Schools-based}

School-based programs were a high focus for Bankstown City Council, as a result of receiving a grant and dedicating a staff position to work with and in schools. This work covered a range of activities, for example, delivering face to face education in classrooms, running the Tree Troopers program (combining tree planting and educational elements), schools bushcare programs, and organising school excursions. 
Randwick City Council organises an annual 'networking afternoon tea' with the Mayor, for local primary and secondary school teachers, to enable schools to meet council staff and learn more about the wide range of council activities that they might be able to incorporate into the curriculum, and the various ways that council might be able help them.

Examples of other activities identified by participating councils included:

o General schools education support - distribution of newsletter quarterly, competitions for primary schools

o Responding to inquiries from students working on school assignments

o Green Schools Funding Program - provide up to $\$ 500$ to schools to undertake environmental education/improvement works

o School water audits

o Development of materials and programs for primary schools including Blue Planet Primary Schools website; and managing a water education program for primary schools called Central Coast Watertight

o Schools exchange - children exchange between city and country schools, to learn about each others' different environments

o Native Haven, schools planting program

o Hosting tours for school students of sites demonstrating water, wastewater, resource recovery technology

o Facilitating a forum where teachers can discuss and share resources.

o Wastewatchers program in schools, 'rubbish free lunch' challenge.

\section{- Early childhood sector}

Activities in this sector included:

o Links with early childhood educators - for example, a number of events for early childhood/lower primary school aged children, and a workshop for the NSW Early Childhood Environmental Education Network

o Preschool education programs and staff support - including regional water education program with preschool staff, professional development workshops for early childhood educators. ( The Little Green Steps preschool education program runs as a regional program with resources available for others to use - originally made possible with funding from the NSW Department of Education and 


\section{Training.)}

o Delivery of programs for children in childcare.

\section{- Residential sector}

Many councils run some kind of education/engagement program for residents, focussed on home-based pro-environmental actions. These often take the form of a series of workshops on different 'sustainable living' topics. For example, Randwick City Council runs an extensive series of 'sustainable urban living' workshops in partnership with the local community college, on topics ranging from sustainable gardening, to biodiversity/bushcare and energy, water and waste issues in the home. These workshops attract between 15 and 40 people, who form connections with each other that can help to extend their learning and involvement beyond the actual course. Other examples of this type of activity include 'non-toxic living workshops' run by Mosman Council, Bankstown City Council's participation in the Australian Conservation Foundation's Green Home program of workshops, and Wyong Shire Council's support of the Vox Bandicoot Sustainability Street program.

\section{- Business sector}

It appears that, at least in the past, when it comes to environmental/sustainability education and engagement, councils have had less of a focus on the business sector compared to the residential sector. However a number of examples of educational/engagement activities targeted at businesses were mentioned. These include a sustainable business workshop to promote and support the Sustainability Advantage program, and a Green Leaders program for small business. Some councils had also recognised a need to increase their engagement with the business sector in the future. For example, Orange City Council has plans for a program for business that will allow businesses to 'adopt' a section of creek, engage them in tree planting, and link to promotions for their business.

\section{Place and event based activities}

A number of education/engagement strategies can be described as place-based or as organised around a particular facility. These include public place recycling education, use of an environmental education centre for schools, or of a wildflower garden as focus for education. Another approach is to create opportunities for the community to view 
some of council's various environmental activities, and to turn these into educational opportunities for people to 'learn by seeing'. Randwick City Council takes this approach, organising 'Sticky Beak Days' when various council sites are open for people to view including the council nursery and the stormwater recycling facility. Orange City Council also conducts tours of the local wastewater treatment plant and resource recovery centre. There are also two examples of a facility having been specifically built for the purposes of environmental education and community engagement, namely the Environmental Learning Facility at Orange, and the Watershed in Sydney (a joint initiative between and the Council of the City of Sydney and Marrickville Council).

Many councils use local festivals or fairs as opportunities to conduct environmental/sustainability education activities. Some incorporated these activities in a regular community event - such as the incorporation of water conservation, sustainable building and waste reduction education at the Mosman Festival. However, others have found it challenging to incorporate environmental education activities into a standard event:

There was a big event on Australia Day. We do this annually every year. It's huge, 30,000 people. We don't do any environmental education at that event. We've tried it in the past. But it's just - it's too big. People aren't there for the sort of things that we would be doing, whether it be a plant giveaway or a small stall or something. But we support it in a different way, in that we funded turning it into a carbon neutral event and getting them to promote that and facilitating recycling at the event.

Other councils have created new, specifically badged events as conscious attempts to use a major public event as an educational opportunity for a large number of local residents. The two high profile examples of this are the City of Sydney's Live Green event, and Randwick Council's Eco-Living Fair. Many councils also participate in and coordinate local events and activities for annual national or state wide programs - such as Clean Up Australia Day, Recycling Week, Water Week, Bike Week and National Tree Planting Day.

\section{Conclusions}

It is difficult to neatly summarise the wide range of approaches identified by this research, or to generalise about 'the current approach' to environmental/sustainability education in NSW. Indeed, the small number of councils interviewed, while diverse and displaying a range of different characteristics, were not intended to be representative of 
NSW councils in general. Nevertheless the research was able to access the views and ideas of a group of people who are significant in the field. Many of the interviewees have developed a high level of experience and significant knowledge in environmental and/or sustainability education, gained through their work over many years and in multiple councils. This recognised expertise perhaps lends some additional weight to the findings. One central observation is that it is striking that such a diverse range of activities were being undertaken across the participating councils. There were many different dimensions of this diversity, from the topic or content areas addressed by the activities, to the types of activity, the delivery methods, the target audiences and so on. Clearly, if the participating councils are anything to go by, local councils are engaged in an extremely broad range of environment/sustainability education activities, and while there are some similar programs being run in different councils, there is clearly no 'one way' for local councils to deliver this kind of education and no standard approach. The participating councils are undertaking a multiplicity of activities and while many identified individual officers or work units for whom environmental/sustainability education is a main focus, it was also common for education to occur in the activities of staff across the organisation.

This lack of a standard approach creates a high degree of flexibility for councils to develop programs that suit their community, that respond to community needs and interests and local environmental data, and that are feasible within councils' own resource constraints. This flexibility is positive, and indeed essential if councils are to develop education strategies that are context-appropriate. However, it is also possible that the lack of a prescribed or preferred 'palette' of programs and activities means that it is fairly resource intensive for each council to develop these kinds of programs 'from scratch'. One possibility worth exploring with local councils is whether there might be support for a more coordinated approach to program development. This could involve a number of councils working together to develop programs or modules that could be implemented (with local adjustment if necessary) in each of their communities. This might be an especially rewarding approach for smaller councils that could benefit from pooling resources. Some of the participants are already taking this approach - in 'piggybacking' some of their educational activities onto existing state government programs for example, or researching successful programs used in other jurisdictions and adapting them for local needs. 
Another observation is that there is perhaps a lack of clarity about the appropriate scope of council environmental/sustainability education activities. Coupled with the funding and staffing constraints faced by many councils, the potentially enormous scope of such work poses ongoing challenges. A number of participants discussed this issue, including questioning their role as education providers (in schools for example), the amount of resources and staff time they should be dedicating to these activities, and 'where to draw the line' on the whole range of environmental issues that communities are interested in learning about. This challenge for councils in trying to be 'all things to all people' is only likely to grow as community awareness of and interest in environmental/sustainability issues (notably climate change) continues to increase, while at the same time many councils’ operating environments remain characterised by severe financial constraints and competing priorities.

\section{References}

DECC 2004. 'Does your project make a difference? A guide to evaluating environmental education projects and programs', DEC 2004/110 $<$ http://www.environment.nsw.gov.au/community/projecteval.htm>

The United Nations principles of Education for Sustainable Development (see UN Decade of Education for Sustainable Development website)

UNESCO 2009. 'UNESCO World Conference on Education for Sustainable Development Proceedings', UNESCO World Conference on Education for Sustainable Development United Nations Educational, Scientific and Cultural Organization, the German Federal Ministry of Education and Research (BMBF), and the German Commission for UNESCO, Bonn, Germany, <http://www.esd-world-conference2009.org/fileadmin/download/ESD2009ProceedingsEnglishFINAL.pdf>

\section{Further information}

(All websites accessed July 2010)

\section{ACF Green Home:}

$<\underline{\text { http://www.acfonline.org.au/default.asp?section_id=86> }}$

Blue Planet:

$<\underline{\text { http://www.blueplanet.nsw.edu.au }}>$

Bushcare:

$<\underline{\text { http://svc018.wic008tv.server-web.com/page.asp?pID=80 }>}$

Central Coast Watertight program: <http://gwcwater.nsw.gov.au/index.php/education/210>

Clean Up Australia Day: $<\underline{\text { http://www.cleanup.org.au/au }>}$

Coastcare:

$<\underline{\text { http://www.coastcare.com.au }>}$ 
Environmental Learning Facility (Orange City Council):

$<$ http://www.netwaste.org.au/projects/envLearnFac.htm>

Estuary Management Plan (Wyong Shire Council): < $\underline{\text { http://www.wyong.nsw.gov.au/environment/tuggerah_estuary_study.html> }}$

Live Green (Council of the City of Sydney): < $\underline{\text { http://www.cityofsydney.nsw.gov.au/environment/LiveGreen/WhyLiveGreen.asp }>}$

Little Green Steps (Wyong Shire Council): <http://www.wyong.nsw.gov.au/environment/preschool_environmental_edu.html $>$

Local Food Futures Alliance (Coffs Harbour City Council): <http://www.coffsharbour.nsw.gov.au/www/html/4069-overview.asp $>$

National Recycling Week: $<$ http://recyclingweek.planetark.org >

National Water Week: $<$ http://www.nationalwaterweek.org.au $>$

National Tree Day: $<\underline{\text { http://treeday.planetark.org }>}$

Nature Conservation Council Climate Consensus Project: $<$ http://nccnsw.org.au/index.php?option=com_content\&task=view\&id=2488\&Itemid=1133>

NetWaste: $<\underline{\text { http://www.netwaste.org.au }}>$

Non-toxic living (Mosman Municipal Council): <http://www.mosman.nsw.gov.au/events/1199/non-toxic-living>

NSW Bike Week: <http://www.rta.nsw.gov.au/usingroads/events/bikeweek/index.html $>$

NSW Early Childhood Environmental Education Network: <http://www.earlychildhoodaustralia.org.au/nsw branch/eceen.html $>$

Sustainability Advantage:

< $\underline{\text { http://www.environment.nsw.gov.au/sustainbus/sustainabilityadvantage.htm> }}>$

Sustainability Street:

$<\underline{\text { http://www.voxbandicoot.com.au/sustainability_street.html }>}$

Sustainable Urban Living courses (Randwick Council): $<$ http://www.randwick.nsw.gov.au/Looking_after_our_environment/Sustaining_our_city/cours es_and_events/Sustainable_Urban_Living_courses/index.aspx $>$

Watershed (Council of the City of Sydney and Marrickville Council): <http://www.cityofsydney.nsw.gov.au/Environment/TheWatershed/Default.asp> 